\title{
Socio-Economic Impacts of Road Infrastructure Development During- and Post-Construction in a Fast-Growing City in Nigeria
}

\author{
Nathaniel Oluwaseun Ogunseye ${ }^{1}$, Oluwaseun Emmanuel Oyejola ${ }^{1}$, Umar Obafemi Salisu ${ }^{1}$, \\ Surajudeen Oluseyi Momodu ${ }^{1}$, Simeon Oluwagbenga Fasina ${ }^{1}$
}

${ }^{1}$ Department of Urban and Regional Planning, Olabisi Onabanjo University, Ago-Iwoye, Ogun State, Nigeria

\begin{abstract}
Road infrastructure is vital to the development of any human settlement and thus it remains an integral part of the municipalities' annual budget. Despite the numerous benefits road infrastructure development (RID) offers, its development imposes negative impacts. While literature is replete with studies on socio-economic impacts of RID at post-construction stage, attention has not been paid to impacts during construction. Consequently, this study aims at analysing the socio-economic impacts of RID during- and post-construction in Abeokuta city in Nigeria. Multistage sampling technique was utilised in sample selection for the study. Both descriptive and inferential statistics were adopted for data analysis with the aid of Statistical Package for Social Sciences (SPSS). Findings from the descriptive analysis indicated that residents were adversely impacted during construction in areas such as business activities, travel rate, property value, vehicle condition and community health. Regression analysis revealed road development statistically impact on socio-economic activities during construction with three out of nine predictors: transport fare $(\mathrm{p}=0.009)$, business activities $(\mathrm{p}=0.015)$, and community health (0.031) exerting the major influence. Also, at post-construction stage, regression analysis revealed road development statistically impact the socio-economic activities with four of the nine predictors: transport fare $(\mathrm{p}=0.042)$, business activities $(\mathrm{p}=0.009)$, community health $(\mathrm{p}=0.035)$, and property value $(\mathrm{p}=0.003)$ exerting the most significant influence. Student t-test results showed that statistical difference existed between 'during construction' and 'post-construction' impacts regarding property value, business activities, community health and transport fare. Finally, the study suggested ways to mitigate problems associated with RID, particularly during construction.
\end{abstract}

Keywords Abeokuta, construction, Nigeria, road infrastructure development, socio-economic impact

JEL : R49

\section{Introduction}

Transport is regarded as the "engine of growth and development in any economy" [1]. As a public utility, transport supplies essential goods and services, the absence of which can result in a total or partial collapse of an economy [2].

The importance of transport to any nation can be appreciated if it is considered that it provides for economic, social, political, cultural and technological needs of individual and society [1]. The varied roles stem from the fact that human activities are not concentrated in just a lo cation, and therefore, the need for man to access the diverse

needs, ranging from shelter, recreation, work, social interaction, religious, and to commercial activities [3]. It is on this premise that transport is being described as "lifelines for people and society" [4]. But when road infrastructure is undeveloped in any human settlement, for certain reasons, economic costs are imposed [5]. Similarly, reference [6] posited that the transport development process is not without externalities such as pollution, noise, dirt and congestion, which affect people's health and climate change.

Studies have been conducted focusing on the impact of road infrastructure development globally. Reference [4] studied the socio-economic impacts of road condition on low volume roads in rural areas of the northern periphery of Europe. Johansson was interested in the socio-economic considerations taken by the road management of partner countries (Scotland, Norway, Sweden and Finland) and concluded that the "target standards for the general road conditions and lowest acceptable standards are more or less expressed and socioeconomic models are used for budget discussions and budget distribution." Reference [7] the impact of road construction on the socio-economic condition of the communities in the hilly terrain of Lunglei district, Mi- 
zoram, India and results revealed that road construction brought about an improvement in the community livelihood and increase in the number of educational and health centres. Also, there was an increased number of people in certain jobs such as carpentry and handloom, and further, stimulate the efficiency of import and export of goods and services.

Reference [8] posited that the construction of North Coast Highway in Jamaica affects diverse stakeholders. Study results indicate that almost $50 \%$ of the respondents have positive perceptions of the North Coast Highway. Most of the respondents adduced the positive perception to the ability to travel with ease. Other benefits identified by respondents include a reduction in flooding due to construction of proper drainage system; less wear and tear on motor vehicles; improved safety and driving conditions; and more trading opportunities as there are inflows of more persons (traders who sell from outside). Conversely, most respondents complained of spending less time with their family, which they attributed to traffic congestion in the North Coast Highway. In another study by Reference [5], the socio-economic impact of road development in Ethiopia with a focus on three roads comprising Gendewuha-Gelago, Mile-Weldiya and Gindi-Kachisi were conducted. Findings show that positive impacts are more than negative impacts across the three corridors despite differences among the different locations. Also, the result indicated that paved highway generates more positive impacts compared to gravel roads. Again, it is noteworthy that Bogale's study focuses on the description of the socio-economic conditions of the residents both before and after the road construction. Reference [9] examined socio-economic benefits and environmental impacts of Thika Road superhighway in Nairobi, Kenya and results revealed that roads development had majorly positive impacts in the areas of investment opportunities and market opportunities whereas the negative impacts are pronounced in the environmental aspects particularly vegetation and wildlife. Reference [10] investigated how highway development and road expansion affect the structure and the general setting of Abeokuta city in Nigeria. Findings indicated that the study area experienced free and smooth traffic flow; increased inflow of residents and businesses into the study area resulting in high demand for housing, and then property value; as well as the opening up of the study area for greater business activities culminating in high cost of rents and leases.

In Nigeria, road transportation is the predominant mode with over $90 \%$ of domestic freights and passengers being moved by this mode $[1,11]$. This overdependence has been linked to its advantages of accessibility, flexibility and availability [1]. It is also noteworthy that the demand for urban transport has been on the rise due to growing urban population throughout Nigerian cities [12]. However, the road network is being described as poor except for Abuja, which is a new city having modern roads and an extensive network of the pedestrian walkway [12]. While roads in Nigeria are in deplorable condition, the efforts by the government to address the issue are also noteworthy as over $60 \%$ of the national investment on transportation has been allocated to road transport infrastructure [1].

Given the above background, it is evident that there is a correlation between the construction of road facilities and the economic development of a city. It is also worth noting that road development impacts could either be direct or indirect. There are also impacts "during construction, those along a newly completed road, and those with long-term impacts" [9]. However, most studies focus on the impacts of the road construction after completion, but there is a dearth of study particularly in developing countries including Nigeria that examined road infrastructure development impacts during construction and post-construction phases. This study aims at analysing the impact of the road construction during- and post-construction stages on the socio-economic development of Abeokuta metropolis. The specific objectives are to examine wide-ranging impacts of road infrastructure development on business (commercial) activities, travel rate, property value, road accident occurrence, transport fare, vehicle condition, community health/wellness, commuting choice and gender travel. It is hoped that the results of the study would help policymakers appreciate the variations between road infrastructure development impacts duringand post-construction stages, and more importantly, inform policy and aid decision-making regarding road infrastructure development for the overall benefits of the populace not only in the study area but across Nigerian cities and other cities embarking on similar projects.

\section{Study Area}

Abeokuta, the capital of Ogun State of Nigeria, lies between $7^{\circ} 15 \mathrm{~N}$ and longitude $3^{\circ} 25 \mathrm{E}$. The city is about $81 \mathrm{~km}$ southwest of Ibadan, the capital of Oyo State and $106 \mathrm{~km}$ north of Lagos State, the former capital of Nigeria. Its population based on the 2006 National Population Commission census was put at 451,607 persons. It has been projected to reach 1.2 million by 2025 . Abeokuta is the cradle of western education in Nigeria as it embraced first set of missionaries over 170 years ago [13]. Abeokuta city encapsulates Abeokuta North and Abeokuta South local government areas (LGAs) (Figure 1). 


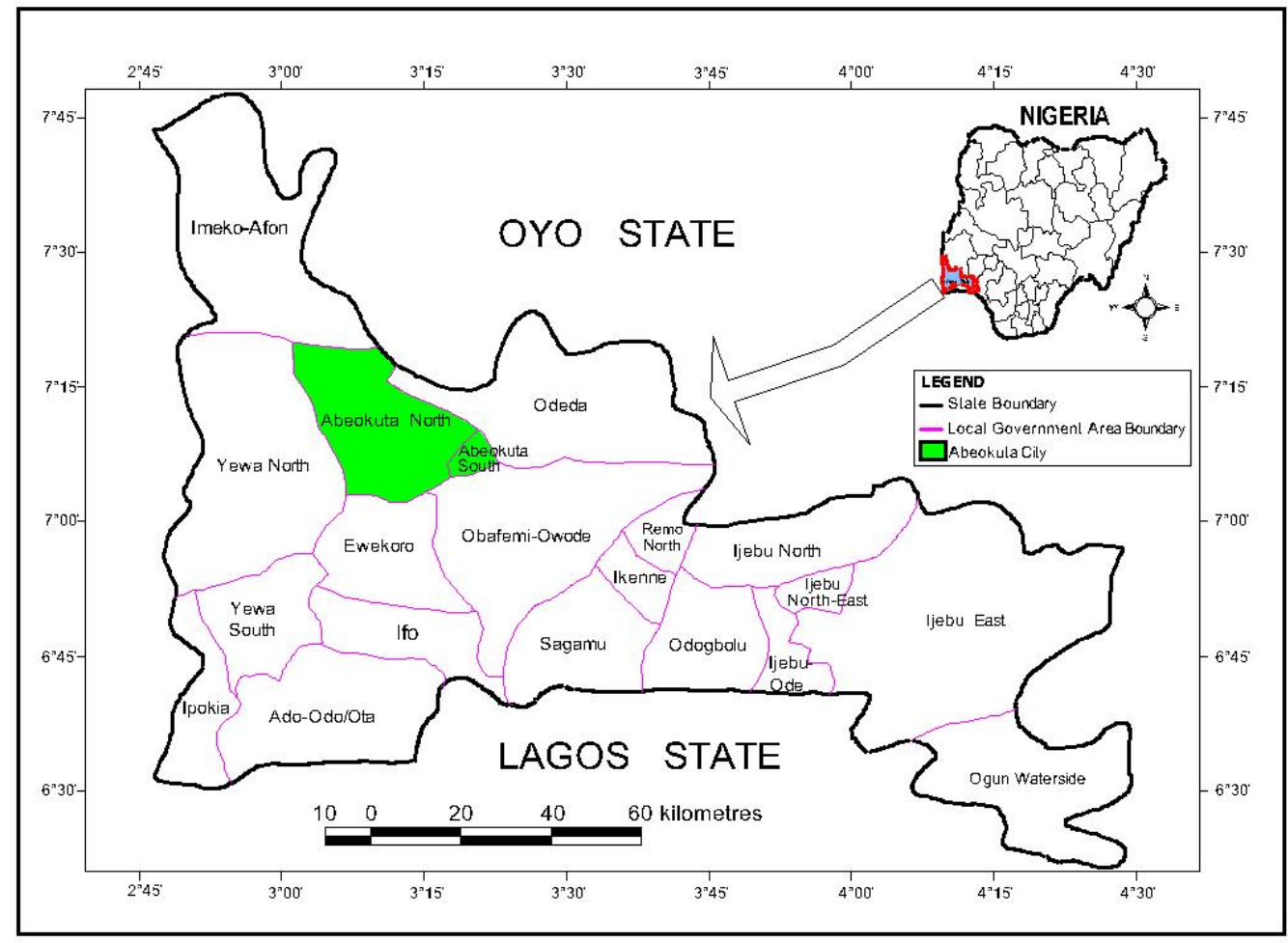

Figure 1. Map of Abeokuta city in Ogun State, Nigeria

\section{Materials and Methods}

This study utilised questionnaire as data collection instrument. The questionnaire contained a combination of closed and open-ended questions. The questionnaire was divided into three sections. Section A captures the socioeconomic data such as gender, age, marital status, employment status, occupation and education. Section B focuses on impacts during the construction phase and the questions posed addressed impacts on businesses, travel rate, property value, accident rate, transport fare, vehicle condition, community health and commuting choice. Section $\mathrm{C}$ deals with impacts in post-construction phase; to which similar questions in the case of during construction were posed. Also, literature review was conducted and it forms the background for this study.

To select samples for the study, a multistage sampling technique was adopted. The first stage involves a stratified sampling technique whereby two LGAs (Abeokuta North and Abeokuta South) that makeup Abeokuta city were selected. At the second stage, the convenience sampling technique was used to select one route each from the selected LGAs. The selected routes are Moore Junction-Adatan Road and Onikolobo-Panseke Road. While Moore Junction-Adatan Road is situated in Abeokuta South local government area (LGA) and is 1.6-kilometre-long, Onikolo
bo-Panseke Road is in Abeokuta North LGA and is about 800 metres in length. The selected routes were major roads of 12 metres right-of-way and the adjoining developments along them were dominated by mixed-use developments particularly residential and commercial land uses. The last stage was where 30 questionnaires each were administered among the residents along the two selected routes using a random sampling technique. Overall, 60 questionnaires were administered which form the sample size.

The data collected were analysed using both descriptive (frequencies and percentages) and inferential (regression and paired sample Student " $t$ " test) statistics. The analytical tool used was the Statistical Package for Social Sciences (SPSS) version 25.

For this study, three hypotheses were formulated and subjected to test. They are as follows:

i. $\mathrm{H}_{0}$ : Road development does not statistically influence or impact socio-economic activities during the construction period

ii. $\mathrm{H}_{0}$ : Road development does not statistically influence or impact socio-economic activities after the construction period

iii. $\mathrm{H}_{0}$ : There is no statistical difference or variation between socio-economic implications during construction and post-construction periods. 


\section{Results}

\subsection{Socio-economic Characteristics of Respondents}

The results show that $53.3 \%$ of the respondents were males while the remaining $(46.7 \%)$ constitute the females. Also, the dominant age group was 20-35 years accounting for $48.3 \%$. It was observed that respondents' travel rate decline with the increase in their age. The majority (55.0\%) of the respondents were married while $45 \%$ were single, thus indicating a potential increase in the population. A larger percentage $(75 \%)$ of the respondents were employed, and the majority $(46.7 \%)$ of whom are civil servants. $75 \%$ of the respondents obtained formal education whereas $23.3 \%$ had informal education, which thus implies that the study area is a literate society.

\subsection{Impacts During the Construction Stage}

Results from analysis of impact on businesses during construction indicated that $43.4 \%$ of the respondents reported late to workplace and $23.3 \%$ experienced low business patronage (Table 1). It was inferred that during the construction, businesses suffered some challenges, particularly lateness to workplace and low business patronage.

Of the total respondents, $55.0 \%$ said their travel rate was negatively affected during construction while $45.0 \%$ thought otherwise. The reasons adduced for the reduced travel rates were traffic congestion (31.6\%), air pollution (dust) $(28.3 \%)$, plying longer routes $(15 \%)$, bad roads $(13.3 \%)$, and a late notice of road diversion (Table 1).

During construction, the majority $(46.7 \%)$ of the respondents opined that there was no impact on property value whereas $41.7 \%$ believed it has an impact. The impacts imposed were in form of building loss $(40 \%)$ and loss of land $(25.0 \%)$ (Tables 1$)$. Loss of buildings implies that property owners have to be compensated. But this is dependent on whether the property owners possess the certificate of occupancy (a legal document), recognised by the Nigeria's Land Use Act of 1978. In this case, the State government takes responsibility for the payment of compensation to the affected property owners. For those who experienced the loss of land, they lacked spaces to perform some functions within their allotments. Though for parking-related function, they resort to on-street parking.

Road accident occurrence during construction is marginal as affirmed by $26.7 \%$ of the respondents. The road accident occurrences were linked to lack of traffic direction (23.3\%), over speeding (18.3\%) and poor road condition (16.7\%) (Table 1).

$38.3 \%$ of the respondents opined that during road construction there was an increase in transport fare while $13.3 \%$ claimed a reduction. The remaining $30.0 \%$ stated no variations (Table 1). The results suggest inconsistencies in transport fare charges caused by lack of regulation of the commercial transport operators' activities.

Again, $36.7 \%$ of the respondents stated that during road construction their vehicles were prone to series of mechanical faults, 29.3\% complained of damages to tyres, and $11.7 \%$ identified impacts such as damaged shock absorber and wheel alignment problems (Table 1). With the majority $(68.4 \%)$ having issues with their vehicles, it can be deduced that vehicles condition deteriorate faster during the construction stage.

In Table 1, the results on impact on commuting choice during construction indicated that $53.3 \%$ of the respondents preferred public transport over private transport (41.7\%). The choice of commuters may have been influenced by the damages caused to their private vehicles. It is noteworthy that, with the considerable percentage still preferring private transport indicate that there are respondents who could not compromise privacy and convenience that private transport offered compared to public transport.

Analysis of impact on community health during construction stage shows that $66.7 \%$ of the respondents were affected by air pollution (dust), equal proportion (13.3\%) experienced catarrh and body pain, and $1.7 \%$ complained of headache, fever, nausea, and itching eyes (Table 1). 
Table 1. Impact During Construction

\begin{tabular}{|c|c|c|c|}
\hline & & Frequency & Percent \\
\hline \multirow{6}{*}{$\begin{array}{l}\text { Impact on } \\
\text { businesses }\end{array}$} & Low patronage & 14 & 23.3 \\
\hline & Increase patronage & 9 & 15.0 \\
\hline & Easy access to work & 3 & 5.0 \\
\hline & Lateness to work place & 26 & 43.4 \\
\hline & No response & 8 & 13.3 \\
\hline & Total & 60 & 100.0 \\
\hline \multirow{3}{*}{$\begin{array}{l}\text { Impact on travel } \\
\text { rate }\end{array}$} & Yes & 33 & 55.0 \\
\hline & No & 27 & 45.0 \\
\hline & Total & 60 & 100.0 \\
\hline \multirow{7}{*}{$\begin{array}{l}\text { Reasons for } \\
\text { travel rate }\end{array}$} & Bad roads & 8 & 13.3 \\
\hline & Air pollution & 17 & 28.3 \\
\hline & Traffic congestion & 19 & 31.7 \\
\hline & Late notice of road diversion & 4 & 6.7 \\
\hline & Plying longer routes & 9 & 15.0 \\
\hline & No response & 3 & 5.0 \\
\hline & Total & 60 & 100.0 \\
\hline \multirow{4}{*}{$\begin{array}{l}\text { Impact on } \\
\text { property value }\end{array}$} & Yes & 24 & 40.0 \\
\hline & No & 28 & 46.7 \\
\hline & No response & 8 & 13.3 \\
\hline & Total & 60 & 100.0 \\
\hline \multirow{4}{*}{$\begin{array}{l}\text { Category of } \\
\text { impact on } \\
\text { property value }\end{array}$} & Loss of building & 24 & 40.0 \\
\hline & Loss of land & 15 & 25.0 \\
\hline & No response & 21 & 35.0 \\
\hline & Total & 60 & 100.0 \\
\hline \multirow{4}{*}{$\begin{array}{l}\text { Impact on road } \\
\text { accident }\end{array}$} & Yes & 16 & 26.7 \\
\hline & No & 39 & 65.0 \\
\hline & No response & 5 & 8.3 \\
\hline & Total & 60 & 100.0 \\
\hline \multirow{6}{*}{$\begin{array}{l}\text { Causes of road } \\
\text { accident }\end{array}$} & Poor road condition & 10 & 16.7 \\
\hline & Lack of traffic direction & 14 & 23.3 \\
\hline & Over speeding & 11 & 18.3 \\
\hline & Others & 1 & 1.7 \\
\hline & No response & 24 & 40.0 \\
\hline & Total & 60 & 100.0 \\
\hline \multirow{5}{*}{$\begin{array}{l}\text { Impact on } \\
\text { transport fare }\end{array}$} & Increase & 23 & 38.4 \\
\hline & Reduction & 8 & 13.3 \\
\hline & No changes & 18 & 30.0 \\
\hline & No response & 11 & 18.3 \\
\hline & Total & 60 & 100.0 \\
\hline \multirow{5}{*}{$\begin{array}{l}\text { Impact on } \\
\text { vehicle } \\
\text { condition }\end{array}$} & Prone to mechanical faults & 22 & 36.7 \\
\hline & Bad tyres and wheels & 12 & 20.0 \\
\hline & $\begin{array}{l}\begin{array}{l}\text { Shock absorber \& wheel align- } \\
\text { ment problems }\end{array} \\
\end{array}$ & 7 & 11.7 \\
\hline & No response & 19 & 31.7 \\
\hline & Total & 60 & 100.0 \\
\hline \multirow{4}{*}{$\begin{array}{l}\text { Impact on } \\
\text { commuting } \\
\text { choice }\end{array}$} & Public transportation & 32 & 53.3 \\
\hline & Private transportation & 25 & 41.7 \\
\hline & No response & 3 & 5.0 \\
\hline & Total & 60 & 100.0 \\
\hline \multirow{6}{*}{$\begin{array}{l}\text { Impact on } \\
\text { community } \\
\text { health }\end{array}$} & Dust (air pollution) & 40 & 66.7 \\
\hline & Catarrh & 8 & 13.3 \\
\hline & Body pain & 8 & 13.3 \\
\hline & Others & 1 & 1.7 \\
\hline & No response & 3 & 5 \\
\hline & Total & 60 & 100.0 \\
\hline
\end{tabular}




\subsection{Post-Construction Impacts}

The results from Table 2 regarding impacts on businesses after construction revealed that $21.7 \%$ of the respondents experienced an increase in patronage, $38.3 \%$ opined that new road provides easy access to work and business locations, and $18.3 \%$ stated low patronage. It can be implied from the results that the new roads have positive effects on business due to smooth surfaces, and the free flow of traffic.

The newly constructed road increased the travel rate as the respondents are willing to commute to and fro within the study area. This assertion was supported by the results indicating that the majority $(58.3 \%)$ of the respondents were encouraged to travel frequently. The reasons for the increase in travel rates were mainly easy traffic flow $(61.7 \%)$, easy accessibility (25.0\%), and reduced risk of accident (13.3\%) (Table 2). Smooth tarred surfaces and wide roads encourage more travels, allay fear of traffic congestion due to poor and narrow roads, or incidences of the faulty vehicle.

Regarding property value, the results revealed almost half $(48.2 \%)$ of the respondents agreed to the value-added impact of road construction and $51.8 \%$ did not agree. The actual impacts on property value were in form of increased property rentals $(30 \%)$, property accessible by road $(11.7 \%)$, aesthetic (1.7\%), and $15 \%$ constitute those with multiple impacts like aesthetic and improve accessibility or even aesthetic and increased property value (Table 2 ).

The post-construction impact on accident rate revealed that $63.3 \%$ of the respondents disagreed that newly constructed road caused accidents whereas $30 \%$ agreed it contributed to the accident rate. The reasons for accident occurrence are over speeding (43.3\%), lack of road furniture (6.7\%), and good road condition (1.7\%) (Table 2).

The results on post-construction effect on transport fare showed the transport fare increase despite the good road condition. The increment in fare may be due to other factors like immigration to the study area, being the capital city, which most times is characterised by high living standards as witnessed in Nigerian capital cities. An earlier study by [10] confirmed inflow of residents into Abeokuta as a result of highway development and expansion.

The post-construction impact on vehicle condition reveals that $20.0 \%$ of the respondents perceive an improvement in vehicle condition, $23.3 \%$ stated that tyres last longer when compared to the construction stage, and $21.7 \%$ said there were fewer issues of repair of shock absorber, wheel alignment and balancing (Table 2). The results imply that vehicle owners would have their expenses on servicing and repairs reduced as compared to during construction.

The result of the post-construction impact on commuting choice showed that over half $(53.3 \%)$ of the respondents preferred to travel by public transportation, $31.7 \%$ chose private transportation and $15.0 \%$ were undecided on their preferences as a result of the impact.

The improvement in community health at post-construction phase can be linked-to the absence of the externalities imposed by construction processes. Results showed that $43.3 \%$ of the respondents had easy access to the other services within the community, $36.7 \%$ commute without stress and $10 \%$ confirmed they spent less time on the road.

Table 2. Post-Construction Impact

\begin{tabular}{|c|c|c|c|}
\hline \multirow{7}{*}{$\begin{array}{l}\text { Impact on } \\
\text { businesses }\end{array}$} & & Frequency & Percent \\
\hline & Low patronage & 11 & 18.3 \\
\hline & Increase in patronage & 13 & 21.7 \\
\hline & Easy access to work & 23 & 38.3 \\
\hline & Others & 6 & 10.0 \\
\hline & No response & 7 & 11.7 \\
\hline & Total & 60 & 100.0 \\
\hline \multirow{3}{*}{$\begin{array}{l}\text { Impact on travel } \\
\text { rate }\end{array}$} & Yes & 35 & 58.3 \\
\hline & No & 25 & 41.7 \\
\hline & Total & 60 & 100.0 \\
\hline \multirow{4}{*}{$\begin{array}{l}\text { Determinants of } \\
\text { travel rate }\end{array}$} & Easy accessibility & 15 & 25.0 \\
\hline & Free flow of traffic & 37 & 61.7 \\
\hline & Reduced risk of accident & 8 & 13.3 \\
\hline & Total & 60 & 100.0 \\
\hline \multirow{4}{*}{$\begin{array}{l}\text { Impact on } \\
\text { property value }\end{array}$} & Yes & 27 & 45.0 \\
\hline & No & 29 & 48.3 \\
\hline & No response & 4 & 6.7 \\
\hline & Total & 60 & 100.0 \\
\hline \multirow{6}{*}{$\begin{array}{l}\text { Category of } \\
\text { impact on } \\
\text { property value }\end{array}$} & Aesthetic outlook & 1 & 1.6 \\
\hline & Nearness to road & 7 & 11.7 \\
\hline & Increase property rentals & 18 & 30.0 \\
\hline & Others & 9 & 15.0 \\
\hline & No response & 25 & 41.7 \\
\hline & Total & 60 & 100.0 \\
\hline \multirow{4}{*}{$\begin{array}{l}\text { Impact on road } \\
\text { accident } \\
\text { occurrence }\end{array}$} & Yes & 18 & 30.0 \\
\hline & No & 38 & 63.3 \\
\hline & No response & 4 & 6.7 \\
\hline & Total & 60 & 100.0 \\
\hline \multirow{5}{*}{$\begin{array}{l}\text { Causes of road } \\
\text { accident }\end{array}$} & Good road condition & 1 & 1.7 \\
\hline & Lack of road furniture & 4 & 6.7 \\
\hline & Over speeding & 26 & 43.3 \\
\hline & No response & 29 & 48.3 \\
\hline & Total & 60 & 100.0 \\
\hline \multirow{4}{*}{$\begin{array}{l}\text { Impact on } \\
\text { transport fare }\end{array}$} & Reduction & 5 & 8.3 \\
\hline & Increase & 29 & 48.3 \\
\hline & No changes & 26 & 43.3 \\
\hline & Total & 60 & 100.0 \\
\hline \multirow{5}{*}{$\begin{array}{l}\text { Impact on } \\
\text { vehicle } \\
\text { condition }\end{array}$} & Improved vehicle health & 12 & 20.0 \\
\hline & Long lasting tyres & 14 & 23.3 \\
\hline & Others & 13 & 21.7 \\
\hline & No response & 21 & 35.0 \\
\hline & Total & 60 & 100.0 \\
\hline \multirow{4}{*}{$\begin{array}{l}\text { Impact on } \\
\text { commuting } \\
\text { choice }\end{array}$} & Public transportation & 32 & 53.3 \\
\hline & Private transportation & 19 & 31.7 \\
\hline & No response & 9 & 15.0 \\
\hline & Total & 60 & 100.0 \\
\hline \multirow{6}{*}{$\begin{array}{l}\text { Impact on } \\
\text { community } \\
\text { health }\end{array}$} & Easy accessibility & 26 & 43.3 \\
\hline & Stress free & 22 & 36.7 \\
\hline & \begin{tabular}{|l} 
Time saving \\
\end{tabular} & 6 & 10 \\
\hline & Others & 1 & 1.7 \\
\hline & No response & 5 & 8.3 \\
\hline & Total & 60 & 100.0 \\
\hline
\end{tabular}




\subsection{Hypotheses Testing}

\subsubsection{Hypothesis I}

$H_{0}$ : Road development does not statistically influence or impact socio-economic activities during the construction period

Further investigations were conducted to establishing the degree of affinity and percentage of causality between the road development (dependent variable) and socio-economic implications (independent variables) during the construction period in Abeokuta, Nigeria using regression analysis. The model specification for the degree of affinity between the dependent variable and independent variables takes the general regression equation model.

$$
\mathrm{Y}=\mathrm{a}+\mathrm{b}_{1} \mathrm{X}_{1}+\mathrm{b}_{2} \mathrm{X}_{2}+\ldots \ldots \mathrm{b}_{\mathrm{n}} \mathrm{X}_{\mathrm{n}}+\mathrm{e}
$$

The results of the regression analysis are presented in Table 3. The regression results show that there is a statistically significant relationship between the road development and socio-economic implications during the construction period in Abeokuta. This result was confirmed through the F-ratio value (2.548) and the observed significant value $(\mathrm{p}=0.017)$ in the summary of ANOVA in the regression table. While comparing the observed significant value with the table value, it is clear that the observed significant value $(\mathrm{p}=0.017)$ is less than the table significant value $(0.05)$. Hence we accept the alternative hypothesis $\left(\mathrm{H}_{1}\right)$ and reject the null hypothesis $\left(\mathrm{H}_{0}\right)$. This implies that road development statistically influences or impacts the socio-economic activities during the construction period in the study area. Furthermore, the coefficient of determination $\mathrm{R}^{2}$ has a value of $31 \%$ meaning that the combined influence of the nine (9) independent variables is over $30 \%$ on the dependent variable (road development) as an explained variation. The observed low percentage of the coefficient of determination was as a result of the nature of data used for the analysis (qualitatively obtained data and quantitatively transformed data). In other words, the unexplained variation might be due to other factors that were not captured as well as the nature of data used.

Meanwhile, three (3) out of the nine (9) predictors: transport fare $(\mathrm{p}=0.009)$, business/trade activities $(\mathrm{p}=0.015)$, and community health/wellness $(\mathrm{p}=0.031)$ have a positive relationship with road development, that is, they exert the most significant factors that influenced or impacted by road development during construction period, while other factors have no negative relationship with road development during construction in the study area.

\subsubsection{Hypothesis II}

$H_{0}$ : Road development does not statistically influence or impact socio-economic activities after the construction period

Also, an investigation was conducted to establishing the degree of affinity and percentage of causality between the road development (dependent variable) and socio-economic implications (independent variables) after construction period in Abeokuta, Nigeria using regression analysis. The results of the regression analysis are presented in Table 4. The regression results show that there is a statistically significant relationship between the road development and socio-economic implications after the construction period in the study area. This result was confirmed through the F-ratio value (2.395) and the observed significant value $(\mathrm{p}=0.024)$ in the summary of ANOVA in the regression table. While comparing the observed significant value with the table value, it is clear that the observed significant value $(\mathrm{p}=0.024)$ is less than the table significant value (0.05). Hence we accept the alternative hypothesis $\left(\mathrm{H}_{1}\right)$ and reject the null hypothesis $\left(\mathrm{H}_{0}\right)$. This implies that road development statistically influences or impacts the socio-economic activities after the construction period in the study area.

Furthermore, the coefficient of determination $\mathrm{R}^{2}$ has a value of $30 \%$ meaning that the combined influence of the nine (9) independent variables is over $30 \%$ on the dependent variable (road development) as an explained variation. The observed low percentage of the coefficient of determination was as a result of the nature of data used for the analysis (qualitatively obtained data and quantitatively transformed data). In other words, the unexplained variation might be due to other factors that were not captured as well as the nature of data used.

However, four (4) out of the nine (9) predictors: transport fare $(p=0.042)$, business/trade activities $(p=0.009)$, community health/wellness $(\mathrm{p}=0.035)$ and property value $(\mathrm{p}=0.003)$ have a positive relationship with road development, that is, exert the most significant factors influenced or impacted by road development after the construction period, while other factors have no negative relationship with road development after construction in the study area. 
Table 3. Multiple Regression Results Showing Road Development Impacts on Socio-Economic Activities During Construction Period Model Summary

\begin{tabular}{|c|c|c|c|c|}
\hline Model & $\mathrm{R}$ & R Square & Adjusted R Square & Std. Error of the Estimate \\
\hline 1 & $.561^{a}$ & 314 & .191 & .447 \\
\hline
\end{tabular}

ANOVA $^{\mathrm{a}}$

\begin{tabular}{|ll|r|r|r|r|r|}
\hline Model & Sum of Squares & df & Mean Square & F & Sig. \\
\hline \multirow{2}{*}{1} & Regression & 4.585 & 9 & .509 & & 2.548 \\
& Residual & 9.998 & $.017^{0}$ \\
& Total & 14.583 & 50 & .200 & & \\
& & 59 & & & \\
\hline
\end{tabular}

Coefficients $^{\mathrm{a}}$

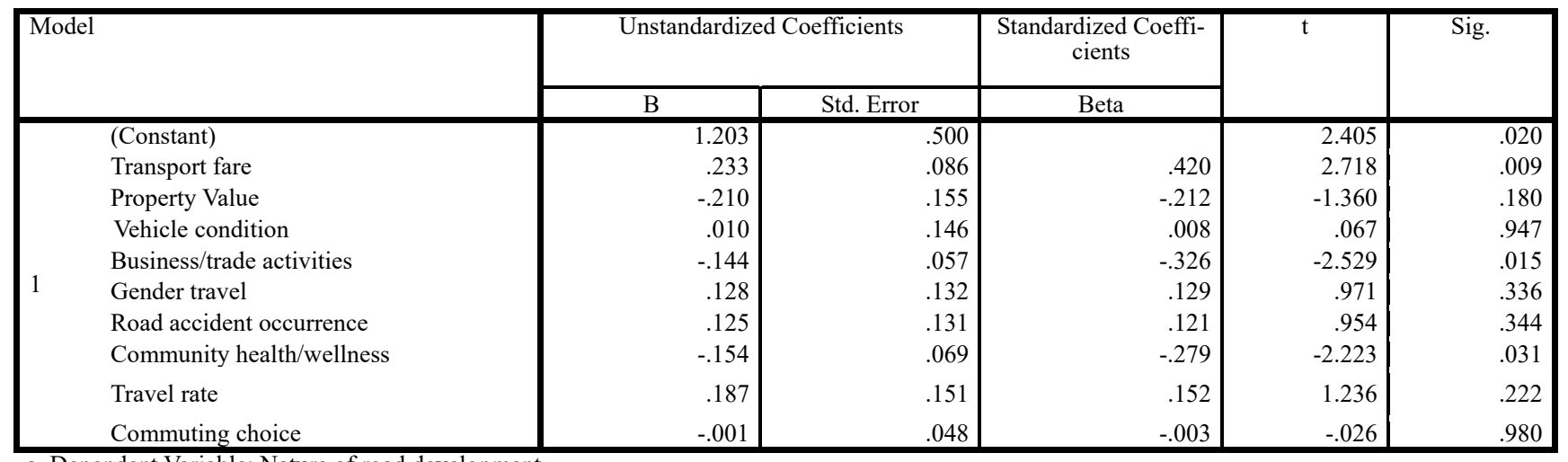

a. Dependent Variable: Nature of road development

Table 4. Multiple Regression Results Showing Road Development Impacts on Socio-Economic Activities After Construction Period Model Summary

\begin{tabular}{|l|r|r|r|r|r|}
\hline Model & R & R Square & Adjusted R Square & Std. Error of the Estimate \\
\hline 1 & & $.549^{\mathrm{a}}$ & .301 & .176 & .451 \\
\hline
\end{tabular}

ANOVA $^{a}$

\begin{tabular}{|c|c|c|c|c|c|c|}
\hline \multicolumn{2}{|c|}{ Model } & Sum of Squares & $\overline{\mathrm{Df}}$ & Mean Square & $\mathrm{F}$ & Sig. \\
\hline \multirow{2}{*}{1} & $\begin{array}{l}\text { Regression } \\
\text { Residual }\end{array}$ & $\begin{array}{r}4.394 \\
10.190\end{array}$ & $\begin{array}{r}9 \\
50\end{array}$ & \multirow[t]{2}{*}{$\begin{array}{l}.488 \\
.204\end{array}$} & \multirow[t]{2}{*}{2.395} & \multirow[t]{2}{*}{$.024^{\circ}$} \\
\hline & Total & 14.583 & 59 & & & \\
\hline
\end{tabular}

Coefficients $^{\mathbf{a}}$

\begin{tabular}{|c|c|c|c|c|c|c|}
\hline \multicolumn{2}{|c|}{ Model } & \multicolumn{2}{|c|}{ Unstandardized Coefficients } & \multirow{2}{*}{$\begin{array}{c}\begin{array}{c}\text { Standardized Coeffi- } \\
\text { cients }\end{array} \\
\text { Beta }\end{array}$} & \multirow[t]{2}{*}{$\mathrm{t}$} & \multirow[t]{2}{*}{ Sig. } \\
\hline & & $\mathrm{B}$ & Std. Error & & & \\
\hline \multirow{10}{*}{1} & (Constant) & 1.274 & .458 & & 2.778 & .008 \\
\hline & Road accident occurrence & -.047 & .085 & -.070 & -.556 & .580 \\
\hline & Travel rate & -.090 & .070 & -.178 & -1.295 & .201 \\
\hline & Vehicle condition & .126 & .123 & .128 & 1.024 & .311 \\
\hline & Commuting choice & .081 & .136 & .079 & .592 & .556 \\
\hline & Gender travel & .035 & .148 & .033 & .236 & .814 \\
\hline & Transport fare & -.177 & .093 & -.241 & -1.910 & .042 \\
\hline & Community health/wellness & .169 & .078 & .275 & 2.164 & .035 \\
\hline & Property Value & .239 & .078 & .411 & 3.070 & .003 \\
\hline & Business/trade activities & -.158 & .058 & -357 & -2.734 & .009 \\
\hline
\end{tabular}




\subsubsection{Hypothesis III}

$H_{0}$ : There is no statistical difference or variation between socio-economic implications during construction and post-construction periods.

Results of the paired sample Student ' $t$ ' test between the socio-economic implications during construction and post-construction periods are presented in Table 5. The summary of the paired sample test shows that four (4) out of the nine (9) analysed factors of the socio-economic implications shows a statistical variation between the two periods, while the remaining five (5) analysed factors exert no statistical variation. Table 6 revealed that there is a statistical difference or variation between impact on property value $(\mathrm{t}=4.810, \mathrm{p}=0.000)$, impact on business/trade activities $(\mathrm{t}=3.034, \mathrm{p}=0.004)$, impact on community health/wellness $(\mathrm{t}=4.786, \mathrm{p}=0.000)$, and impact on transport fare $(\mathrm{t}=4.112$, $\mathrm{p}=0.000)$. Hence, we accept the alternative hypothesis $\left(\mathrm{H}_{1}\right)$ and reject null hypothesis $\left(\mathrm{H}_{0}\right)$ for the above analysed socio-economic factors. This implies that the impact of road development on property value, business/trade activities, community health/wellness, as well as transport fare during construction and post-construction varies or differs.

Table 6 also show that there exist no difference or variation between impact on vehicle condition $(t=0.103$, $\mathrm{p}=0.918)$, impact of gender travel $(\mathrm{t}=1.625, \mathrm{p}=0.109)$, impact on travel rate $(\mathrm{t}=0.468, \mathrm{p}=0.641)$, impact on commuting choice $(\mathrm{t}=0.423, \mathrm{p}=0.673)$ and impact on road accident occurrence $(\mathrm{t}=0.184, \mathrm{p}=0.854)$. Hence, we accept the null hypothesis $\left(\mathrm{H}_{0}\right)$ and reject the alternative hypothesis $\left(\mathrm{H}_{1}\right)$ for the above-analysed factors. This implies that the impact of road development on vehicle condition, gender travel, travel rate, commuting choice and road accident occurrence during construction and post-construction periods does not vary or differs.

Table 5. Student t-test Results Between Socio-economic Implications during Construction and Post-Construction Paired Samples Test

\begin{tabular}{|c|c|c|c|c|c|c|c|c|c|}
\hline & \multicolumn{5}{|c|}{ Paired Differences } & \multirow[t]{3}{*}{$\mathrm{T}$} & \multirow[t]{3}{*}{$\mathrm{df}$} & \multirow[t]{3}{*}{ Sig. (2-tailed) } \\
\hline & & \multirow[t]{2}{*}{ Mean } & \multirow[t]{2}{*}{$\begin{array}{l}\text { Std. Devia- } \\
\text { tion }\end{array}$} & \multirow[t]{2}{*}{$\begin{array}{l}\text { Std. Error } \\
\text { Mean }\end{array}$} & \multicolumn{2}{|c|}{$\begin{array}{l}\text { 95\% Confidence Interval of the } \\
\text { Difference }\end{array}$} & & & \\
\hline & & & & & Lower & Upper & & & \\
\hline $\begin{array}{l}\text { Pair } \\
1\end{array}$ & $\begin{array}{l}\text { Property value (during)- Property } \\
\text { value (post) }\end{array}$ & -.617 & .993 & .128 & -.873 & -.360 & -4.810 & 59 & .000 \\
\hline $\begin{array}{l}\text { Pair } \\
2\end{array}$ & $\begin{array}{l}\text { Vehicle condition (during) - Vehicle } \\
\text { condition (post) }\end{array}$ & -.017 & 1.255 & .162 & -.341 & .308 & -.103 & 59 & .918 \\
\hline $\begin{array}{l}\text { Pair } \\
3\end{array}$ & $\begin{array}{l}\text { Gender travel (during) - Gender } \\
\text { travel (post) }\end{array}$ & .100 & .477 & .062 & -.023 & .223 & 1.625 & 59 & .109 \\
\hline $\begin{array}{l}\text { Pair } \\
4\end{array}$ & $\begin{array}{l}\text { Business/ trade activities (during)- } \\
\text { Business/ trade activities (post) }\end{array}$ & -.600 & 1.532 & . 198 & -.996 & -.204 & -3.034 & 59 & .004 \\
\hline $\begin{array}{l}\text { Pair } \\
5\end{array}$ & $\begin{array}{l}\text { Community health/ wellness (dur- } \\
\text { ing)- community health/ wellness } \\
\text { (post) }\end{array}$ & -.583 & .944 & .122 & -.827 & -.339 & -4.786 & 59 & .000 \\
\hline $\begin{array}{l}\text { Pair } \\
6\end{array}$ & $\begin{array}{l}\text { Transport fare (during) - Transport } \\
\text { fare (post) }\end{array}$ & .350 & .659 & .085 & .180 & .520 & 4.112 & 59 & .000 \\
\hline $\begin{array}{l}\text { Pair } \\
7\end{array}$ & $\begin{array}{l}\text { Travel rate (during) - Travel rate } \\
\text { (post) }\end{array}$ & -.033 & .551 & .071 & -.176 & .109 & -.468 & 59 & .641 \\
\hline $\begin{array}{l}\text { Pair } \\
8\end{array}$ & $\begin{array}{l}\text { Commuting choice (during) - } \\
\text { Commuting choice (post) }\end{array}$ & .033 & .610 & .079 & -.124 & .191 & .423 & 59 & .673 \\
\hline $\begin{array}{l}\text { Pair } \\
9\end{array}$ & $\begin{array}{l}\text { Road accident occurrence (during)- } \\
\text { Road accident occurrence (post) }\end{array}$ & -.033 & 1.402 & .181 & -.395 & .329 & -.184 & 59 & .854 \\
\hline
\end{tabular}




\section{Discussions and Conclusions}

From the business perspective, the patronage increases during the post-construction phase in comparison to during construction. Residents confirmed greater access to the workplace at post-construction, a factor which was a concern during the construction phase. The increased patronage indicates an improvement in the residents' livelihood and economic prospects for residents as they are guaranteed patrons not only within their neighbourhood but outside. This result corroborates findings of studies by [7, 8, 9].

Residents' travel rate improved at the post-construction stage. The result supports the findings of $[8,10]$. The improvement recorded is mainly due to free traffic flow made possible by smooth paved surfaces and improved right-of-way. This new road attributes eliminate problems of traffic congestion, poor road condition, plying the longer alternative route and a late notice of road diversion to the motorists by the construction firm.

The property value appreciated at post-construction phase compared to during construction. Unlike during the construction phase when residents experienced impacts in form of loss of buildings and land area (reduction in available space), residents confirmed an increase in rentals, property proximity to roads and aesthetic outlook contributed to the property value. Reference [10] study affirmed that respondents agreed to road expansion effect on rents and leases.

Public transport fare increment was experienced during construction and post-construction stages, which suggest road construction have little or no impact on the transport fare charged by the motorists. The increment witnessed in the two stages regarding transport fare can be linked to unregulated fare operational in Abeokuta city. Consequently, the amount paid to motorists seem to depend on the bargaining power of the commuters.

The poor vehicle condition is a major problem during the construction stage as vehicles are highly prone to mechanical faults, tyres' wear and tear, and shock absorber and wheel alignment problems. But the post-construction impact indicated an improved vehicle condition with a report that tyres last longer and fewer repairs of the shock absorber and wheel alignment. The result agrees with findings of [10] where respondents reported less wear and tear due to construction of North Coast Highway in Jamaica.

The results obtained during construction and post-construction imply that road accidents occurrence are not greatly dependent on the two construction phases examined in this study. However, road accident occurrences during the construction stage were connected to lack of traffic direction, over speeding and poor road condition. Similarly, over speeding contributed to road accident occurrence after construction. It is important to state that problems of over speeding should be addressed, which can be taken as behavioural and psychological issues.

The regression analyses conducted revealed road development exert significant influence on the socio-economic activities during construction and post-construction stages. During construction, the predictors such as transport fare, business activities and community health exert major influence whereas the predictors with significant influence for post-construction are transport fare, business activities, community health and property value. Also, the Student t-test results established that statistical difference exists between impacts during construction and post-construction stages. The variations in impacts are reflected in the variables of property value, businesses, community health and transport fare. In other words, the impacts of road development during construction and post-construction periods do not vary or differ regarding variables of vehicle condition, gender travel, travel rate, commuting choice and road accident occurrence.

Based on the findings emanating from this study, the following recommendations are put forward. First, the government and construction firms should pre-empt possible externalities and put in place measures that would help mitigate the impacts during road construction on residents. Second, the government should see to the release of funding as well as mandate the construction firms to work within the project schedule so that residents would need not bear unnecessary costs beyond the agreed project life. This is important because it has been observed that sometimes construction firms suspend work when required finances are not mobilised at the appropriate time. Third, public sensitisation before the commencement of the road project and continual update on progress made would give a sense of belonging to the populace and prepare their mind for possible self-initiative to cushion the negative impacts that may emanate from the proposed project. Fourth, early notice regarding traffic diversion is desirable during road development, and lastly, efforts towards adopting best practices in the development of road infrastructure in order to maximize benefits and minimise the externalities are highly recommended.

\section{REFERENCES}

[1] Badejo, B.A., "Transportation: Removing the clogs to Nigeria's development", Anchorage Press \& Publishers, Lagos, 2011.

[2] Bos, D., "Regulation: Theory and concepts", In D. Parker \& Saal, D. (Eds), International Handbook in Privatisation, pp. 447-497, Edward Edgar Publishing Model, Cheltenhan, 2003.

[3] Morenikeji, W. "Land use planning and transport system in cities", In K. M. Yari, Ndirmbula, A. G., Nwosu, E. C. G. \& Badejo, B. A. (Eds), Transportation challenges in Nigerian cities: A synopsis, pp. 15-36, Nigerian Institute of Town Planners \& Town Planners Registration Council of Nigeria, Abuja, 2017.

[4] Johansson, S., "Socio-economic impacts of road condition on low volume roads", Roadex II Northern Periphery, Report being part-financed by the European Regional Development Fund, 2004. 
[5] Bogale, B.D., "Socioeconomic impacts of road development in Ethiopia: case studies of Gendewuha- Gelago, Mile-Weldiya and Ginchi-Kachisi Roads", (Doctoral Thesis), Department of Geography, University of South Africa, 2016.

[6] Oyesiku, O.O., "From Womb to Tomb", 24th Inaugural Lecture at Olabisi Onabanjo University on 27 August 2002. Olabisi Onabanjo University Press, Ago-Iwoye, 2002.

[7] Lalnundanga, Sailo, L., Vanlalbela, C., Malsawmkima, B., "Impact of road construction on the socio-economic condition of the communities in the hilly terrain of Lunglei district, Mizoram, India", Science Vision, vol. 15, no. 3, pp.152-158, 2015.

[8] McGrowder, D., Jackson, L.A., Forrester, R., Edie, C. Crawford, A., Simpson, S., Crawford, T., "The Impact of the North Coast highway on socioeconomic status and family life of residents in Bogue village, Jamaica" Asian Social Science, vol. 5, no. 2, pp.29-37. 2009.

[9] Wanjiku, E.M., "Socio-economic benefits and environmental impacts of Thikaroad superhighway", (Research Project), Kenyatta University, 2014.

[10] Afolabi, O. J., Oyetubo, O. A., Oluwaji, O. A., "Implications of highway development and expansion on urban residents in Nigeria: A case study of Abeokuta metropolis", Nigerian Journal of Technology, vol. 32, no. 2, pp.302-308, 2018.

[11] Badejo, B., "Transportation in Nigerian cities: findings, expectations and future outlook", In K. M. Yari, Ndirmbula, A G., Nwosu, E. C. G. \& Badejo, B. A. (Eds), Transportation challenges in Nigerian cities: A synopsis, pp.123-141, Nigerian Institute of Town Planners \& Town Planners Registration Council of Nigeria, Abuja, 2017.

[12] Ogwude, I.C., "Managing transportation infrastructure in Nigerian cities". In K. M. Yari, Ndirmbula, A. G., Nwosu, E. C. G. \& Badejo, B. A. (Eds), Transportation challenges in Nigerian cities: A synopsis, pp. 74-98, Nigerian Institute of Town Planners \& Town Planners Registration Council of Nigeria, Abuja, 2017.

[13] Ogun State Government, "Ogun State Regional Plan (2005-2025) Final Report”, CPMS Limited, Lagos, 2008. 